\title{
Communities of faith as texts in the process of biblical interpretation ${ }^{1}$
}

L Jonker

(US)

\section{ABSTRACT}

Communities of faith as texts in the process of biblical interpretation

In this article the author illustrates that the relationship between the Bible and the Church could also be described from the post-modern perspective of intertextuality. He argues that communities of faith are texts in an allencompassing network of textuality. However, these texts, as all other texts, are involved in clusters of related texts that show an affinity with one another. Within these clusters the related texts become more prominent and significant than texts "further away" in the network of textuality. He uses this view to argue that the Church, along with the Synagogue, has a special responsibility in the process of interpretation of the written biblical texts.

He also argues that all the approaches that biblical scholars have utilized through the ages, when viewed as different perspectives on the network of textuality, could assist in our reading of communities of faith as texts.

\section{INTRODUCTION}

In recent years renewed attention has been given to the relationship between the Bible and the Church, that is, the Christian communities of faith. A number of publications ${ }^{2}$ in the recent past show that there is a growing concern that the Bible has lost its voice for communities of faith, and that it has to be reclaimed. The points of view expressed in these publications are, of course, differently motivated. Without elaborating on each of the following, and without attempting to be exhaustive, the following divergent convictions can be mentioned:

1.1 Writers with fundamentalist convictions want to liberate the Bible from the so-called tyranny of historical enquiry which dissects the Bible and destroys it as a document of faith. They want to guard the Bible as the inerrant, authoritative Word of God ${ }^{3}$.

1.2 Some writers from mainstream churches, without confessing to fundamentalist principles, express their concern about, what they would call, 
the degrading of the doctrines on the authority and inspiration of Scripture when the human dimensions of the Bible are emphasized 4 .

1.3 Other publications react against an overly-analytical approach to biblical criticism. In many of these publications it is historical criticism, in particular, that is scrutinized critically. It is not historical criticism as such that is criticized, but the so-called insufficiency of this approach to promote theological interpretation. Criticism is also directed at many historicalcritical studies which devote all their attention to Literarkritik and Formkritik (the analytical methods) without paying attention to Redaktionskritik (the synthetical method)s.

1.4 Still other publications pay renewed attention to the relationship between the Bible and the Church from the point of departure that the role of the reader has to be appreciated. Since scholars have realized that reading is a creative process in which the reader contributes to the process of interpretation from a certain perspective, the focus of attention has shifted to the communities of faith as readers of the Bible.

1.5 Some scholars express their appreciation of the interpretations of marginalized and ordinary readers ${ }^{6}$. They emphasize the fact that biblical interpretation is not only the enterprise of a privileged, academic guild of scholars, but also the prerogative of ordinary and marginalized people of faith. Some even say that we have the ethical obligation to side with marginalized and ordinary readers to learn from them ${ }^{7}$.

1.6 In certain contexts the democratization and popularization of academic studies also play an important role in the revival of the discussion on the relationship between the Bible and communities of faith. Scholars are increasingly realizing that biblical studies and exegesis cannot be practised in an ivory tower ${ }^{8}$.

1.7 Still others are interested in the relationship between the Bible and communities of faith, because they appreciate and they want to celebrate a plurality of interpretations. These people are normally committed to the post-modern notion that texts do not bear only one, fixed meaning, but that a plurality of meanings is created when texts are read in different contexts?.

Closely associated with the last-mentioned conviction, namely that of postmodernism, some scholars have recently introduced the notion of inter- 
textuality as a possible mode of description of the relationship between the Bible and communities of faith ${ }^{10}$. These scholars are in favour of rethinking this relationship from the post-modern perspective that communities of faith are part of the intertextual network in which biblical texts operate. I associate myself closely with this perspective, and I will try to elaborate on some aspects of this view in the present article.

\section{INTERTEXTUALITY: A PLURALITY OF VIEWS}

Without repeating in full everything that has been said about intertextuality elsewhere"1, and without elaborating on Bakhtin's and Kristeva's work here, I will firstly deal with different views on textuality in this section. Thereafter, I will clarify which view of intertextuality I will apply in this article.

Degenaar 12 has provided a useful summary of different views on language, text, textuality and intertextuality. I will here concentrate on his categorization of the different views on text. He mentions seven possibilities:

2.1 The first view refers to the etymology of the word "text". The Latin word texere means "to weave". The word text would then entail the weaving of words ${ }^{13}$. According to this view a text is then the interweaving of signs, a web of relationships between signs which stand in need of interpretation.

2.2 From a psychological perspective a text is regarded as a document that informs the reader about the state of mind of the author. According to this view the intention of the author becomes the final source of authority regarding the meaning of signs in the text.

2.3 Structuralism regards the text as an autonomous whole, a selfenclosed structure of meaning. The authority for the meaning is inherent in the text itself.

2.4 Structuralism can also function in a different way by viewing the text as a manifestation of a depth structure which constitutes the authority for the meaning.

2.5 Semiotics emphasizes the role of the reader, and holds the view that meaning is manifested in the act of reading the signs of a text. The rela- 
tionship between the text and the performance of the act of reading constitutes the authority for the meaning.

2.6 In terms of a deconstructive reading, a text is an intertextual event ${ }^{14}$. Two views could, however, be distinguished here, a narrower and a broader one. According to the narrower view intertextuality refers to the interrelationships between texts in the normal sense of the word, text as referring to the interweaving of signs in a book, article or poem. Intertextuality is then concerned about the way in which a text refers to other texts ${ }^{15}$, and how these texts relate to one another ${ }^{16}$. According to the broader view intertextuality refers to the interrelationships between texts in the abnormal sense of the word text as referring to any object of understanding. It includes the textuality of all things - "A text becomes an episode in an all-enclosing textuality" 17.

2.7 From a political perspective the text is regarded as a site of struggle ${ }^{18}$ - "By viewing society and history as texts one becomes conscious of the relationships of power between signs which reverberate through all texts, also literary texts. The understanding of meaning is not a neutral affair, but an involvement in a struggle in which choices have been made and are to be made ${ }^{m 19}$.

In my description of the relationship between the Bible and communities of faith I want to link up with the broader deconstructionist view on textuality, as well as with the political view of the text as a site of struggle - "Since the term text is not limited to written texts, the term intertext enables one to bring into play appropriate signs taken from different areas of human experience. These signs come into play, not as external factors, but as part of textuality which enriches the meaning of the written text" 20 .

This broader notion of textuality therefore allows one to propose that communities of faith can be regarded as texts in the process of biblical interpretation. Communities of faith are part of the intertextual network of relationships in which biblical texts are involved. However, when dealing with religious texts as part of culture, one can also regard these texts as sites of struggle. How communities of faith as texts are involved in this struggle will be elaborated on in a later section.

\section{COMMUNITIES OF FAITH AND WRITTEN RELIGIOUS TEXTS}

What role do biblical texts play within different communities of faith? And what influence do different communities of faith have on the meaning of 
biblical texts? These questions already suggest that the relationship between communities of faith and biblical texts should be regarded as reciprocal. On the one hand do communities of faith orientate themselves according to biblical texts. They also understand themselves in the light of these texts; they find their identity formulated by these texts. On the other hand, different communities of faith also contribute to the understanding of these biblical texts. Because of the above-mentioned creative role of the reader, one should also recognize that communities of faith shape these texts "according to their image". That means that communities of faith, as ideologically biased readers, bring along a tradition of interpretation, certain convictions, norms and values, etc. when they engage in reading biblical texts. The reciprocal relationship between biblical texts and communities of faith thus entails: (i) that the written religious texts have an identity-shaping and life-orientating effect on the communities of faith; and (ii) that the communities of faith have a meaning-shaping effect on the written religious texts.

However, one should not view this reciprocal relationship only from a synchronical perspective, that is, a description of the contemporary interaction between biblical texts and communities of faith. This relationship can also be described from a diachronical perspective. Through the ages this relationship has existed on different levels. This relationship is manifested not only on the level of textual reception, but also on the level of textual production. Communities of faith, within the political and cultural world of their time, formulated their religious experiences into initially oral, and later written, texts. These texts exercised an influence in the ever-new attempts at reinterpreting old texts and producing new texts. Textual interpretation or reception triggered renewed textual production. As soon as these texts gained authoritative status among the communities of faith, they became the expression of religious identity, as well as an identity-forming force for later generations. In post-modern language one could say that all texts (written or otherwise) carry traces of other texts (written or otherwise). All these texts exhibit a dialogic character - they are in constant dialogue with other earlier and contemporary texts. All these texts are intersections of other textual surfaces.

The reciprocal processes of textual production and textual reception in ancient and contemporary contexts tend to obliterate the boundaries between these processes. Textual production becomes textual reception, and vice versa. The boundaries between texts and their interpretations become irrelevant. Even the boundaries between what is inside a text, and what is outside, start to vanish. It is on this point that we can utilize the 
post-modern language of intertextuality. biblical texts and the communities of faith that produce and interpret them become part of an allencompassing textuality - part of an intertextual network of relationships that span not only contemporary reality, but also the ages.

\section{THE STATUS OF COMMUNITIES OF FAITH AS TEXTS}

The important questions, of course, are now: "What is the status of communities of faith as texts in this intertextual network of textuality? Do communities of faith have any privileged position within the network of textuality in which biblical texts are involved?".

In terms of a purely deconstructionist view of intertextuality, one would say that no text has any privilege over against other texts. All texts are equal. As Miscall ${ }^{21}$ puts it: “...textual authority and status are always in question since texts are interdependent and use each other. No text is an island". This would mean that communities of faith would have no privileged position with regards to the written biblical texts over against any other text in the all-encompassing network of textuality. The interaction between communities of faith and their written religious texts would be on a par with any other community's interaction with these texts, or other texts. What is important are not the participating texts, but their interrelationship, their intertextuality.

At this point I would like to agree with Beal22, Nielsen ${ }^{23}$, Van Wolde ${ }^{24}$ and others that such a view would make reading impossible. As Beal25 puts it: “...no intertextual reading can choose the 'general text' everything, all at once, everywhere - as its object of interpretation". Or as the often-quoted Fish ${ }^{26}$ has indicated: "... while relativism is a position one can entertain, it is not a position one can occupy. No one can be a relativist, because no one can achieve the distance from his (sic!) own beliefs and assumptions which would result in their being no more authoritative for him (sic!) than the beliefs and assumptions held by others..." (his italics). According to Fish, understanding always takes place contextually. Although there is a plurality of meanings, the beliefs and assumptions of the reader/hearer determine which one of these meanings becomes prominent ${ }^{27}$. However, these beliefs and assumptions "are not individual-specific or idiosyncratic, but communal and conventional" 28 . Fish therefore introduces the now well-known notion of interpretive communities.

If these qualifications of intertextuality by Beal, Fish and others are true, it then follows that a certain degree of framing, or matrixing (as 
Voelz ${ }^{29}$ calls it), is inevitable in intertextual interpretation (over-against intertextual theory). To quote from Beal ${ }^{30}$ again: "For the practice of intertextual reading, however, as opposed to theories of intertextuality, one must have such lines of delimitation, no matter how arbitrarily they may be set, and no matter how quickly they may be transgressed. ...the practice of intertextual reading must find its place somewhere between the closed structure of a single text (however defined) and the uncontainably surplussive fabric of language (called intertextuality)".

How is this matrixing, or framing, done? And what status do communities of faith have in this process of delimitation? Although one could, as Beal, Fish, Nielsen and others do, refer to the beliefs, values, assumptions, etc. of the interpretive community, such a view would locate the decision-making authority solely within the text of the communities of faith. I do not want to deny that the interpretive interests of a community of faith do play an important role in this process. However, I would rather like to focus not on the interpretive communities alone, but on the interaction between texts within the intertextual network.

I would like to suggest that, although one cannot deny the allencompassing nature of the network of intertextuality, one can detect certain clusters of related texts in this network ${ }^{31}$. All texts are equal, but all texts do not have an affinity for each and every other text. This does not mean that each and every other text does not influence the intertextual relationships. This does also not mean that the intertextual network becomes stable and solid again. To use a metaphor from astronomy: although there are an unknown number of heavenly bodies that constantly influence one another, and that are because of this influence in constant motion, there is also a solar system such as ours. Within the all-encompassing universe there are clusters of related bodies that we call solar systems.

This metaphor tries to explain that one should not shy away from acknowledging that within the all-encompassing network of textuality, communities of faith do relate more closely to religious texts as expressions of faith than they do to other texts. Exactly because of their intertextual interaction, they have a closer affinity with one another. There is nothing strange about this cluster of related texts ${ }^{32}$. As Kort ${ }^{33}$ puts it: "Since all communities have language and practices, it can even be said that all languages and practices have their own 'communities' and that there is nothing strange or unusual about the peculiar words and actions of religious communities. Religious communities no longer need think of themselves as exceptional in this regard, since no one reads anything without being located somewhere". 
How are these clusters of related texts formed? In this regard I want to refer back to the political perspective on texts as sites of struggle ${ }^{34}$. To quote Degenaar ${ }^{35}$ again: "By viewing society and history as texts one becomes conscious of the relationships of power between signs which reverberate through all texts, also literary texts. The understanding of meaning is not a neutral affair, but an involvement in a struggle in which choices have been made and are to be maden. These choices are made in and through the clustering of related texts. The choices are made in the different texts' struggle to be heard. With regard to communities of faith, these choices are made in the struggle for identity and meaningfulness within a world of other texts ${ }^{36}$.

Of course one should keep in mind that not all communities of faith feel an affinity for all written religious texts. The Jewish community, for example, operates as text within the cluster of texts of which the Hebrew Bible is a part. The Christian community partly operates within the same cluster of which the Hebrew Bible is a part, but this cluster already becomes transformed because of this community's affinity with another text, that of the New Testament. These cluster-forming processes as struggles for identity and meaningfulness are of course not only something of the past, of ancient times. These processes continue through the ages so that contemporary communities of faith are still part of the same intertextual network. This point again illustrates how the boundaries between textual production (as a struggle for identity and meaningfulness) and textual reception (as a struggle for identity and meaningfulness) are obliterated.

After this lengthy discussion I would like to conclude this section by answering the question: "What is the status of communities of faith?" The status of communities of faith should be understood within the clusters of related texts. For the interpretation of the Hebrew Bible two communities of faith certainly have a more prominent status, namely Judaism and Christianity ${ }^{37}$. Although these communities are not homogeneous, they share certain religious texts as expressions of their identities and meaningfulness. This in itself emphasizes that these two communities of faith as texts are also inevitably in a dialogic relationship. However, Christianity's understanding of the Hebrew Bible takes place in an adapted cluster of texts, a cluster that also includes the New Testament. Within this cluster the Christian Church (in all its variety) has a special responsibility 38 as the context within which the Bible as Old and New Testaments has to be interpreted 39 . The relationship between the Bible and the Church should thus be cultivated, because they are both texts within a certain cluster of related 
texts. However, this relationship should also be cultivated with acknowledgement of the fact that this cluster of related texts in part overlap with another cluster of related texts, and that they are all part of an allencompassing network of textuality. Davies ${ }^{40}$ puts it as follows: "In a very obvious sense, the religious institutions and communities of Judaism and Christianity have a claim on their bibles. This claim is valid within those communities, but to try and universalize it is to deny that these bibles should play any part in study of the cultures of the ancient Mediterranean world, or of Western culture, whose domains include but also extend beyond church or synagogue" 41 .

\section{READING COMMUNITIES OF FAITH AS TEXTS}

A text as a set of signs is always in need of interpretation. This is, of course, also true of communities of faith as texts ${ }^{42}$. Communities of faith as texts, as we have seen above, are intertextually woven into the network of textuality - within clusters of related texts, as well as within the allencompassing textuality. The reading of communities of faith as texts is therefore necessary for the intertextual understanding of other related texts, such as the written biblical texts.

Through the ages various approaches to the reading of written biblical texts have been developed. The modern approaches vary from the historical-critical approach that seeks to illuminate the origins, development and transmission of the written texts, to narrative and structuralist analyses that seek to "unlock" the presumed structures within the written texts themselves, and to reader-orientated approaches that seek to illuminate the contexts in which the written texts are read. Drenched in the spirit of modernism, biblical scholars have often regarded these approaches as means to obtain "objective" meaning, be it from the world behind the texts, the world of the texts, or the world in front of the text. Therefore, scholars often treat these approaches as rigid methods - often coupled with claims of exclusivity. Within such a modernist perspective on these approaches, one would be tempted to regard only the reader-orientated approaches as suitable to investigate communities of faith in their interaction with the written biblical texts.

However, when these approaches are regarded as various perspectives, sometimes complementary and sometimes contradictory, on the allencompassing network of textuality, or even as still another set of texts involved in this network, it becomes clear that all of these approaches could also be used to read communities of faith as texts. A historical- 
critical approach would then, for example, assist in determining the tensions within a not at all homogeneous community of faith. It would also be able to assist in tracing the development of the tradition(s) of interpretation in that particular community of faith. A structuralist-semiotic approach could assist in the description of the interrelationships within that community of faith that determine the prevalent conventions on interpretation, as well as the value systems, beliefs and convictions. A narrative analysis could, for example, assist in determining the themes, characters, elements of tension, etc. that constitute the "plot line" of that particular community of faith.

These approaches, when viewed in this way, then do not have the function of producing "objective truths", but rather serve as different perspectives on the all-encompassing network of textuality, or better still, as participants in the intertextual interplay between, amongst other things, communities of faith and the written biblical texts.

\section{CONCLUSION}

In this article I have attempted to illustrate that the relationship between the Bible and the Church could also be described from the post-modern perspective of intertextuality. I have argued that communities of faith are texts in an all-encompassing network of textuality. However, these texts, as all other texts, are involved in clusters of related texts that show an affinity with one another. Within these clusters the related texts become more prominent and significant than texts "further away" in the network of textuality. I have used this view to argue that the Church, along with the Synagogue, has a special responsibility in the process of interpretation of the written biblical texts.

I have also argued that all the approaches that biblical scholars have utilized through the ages, when viewed as different perspectives on the network of textuality, could assist in our reading of communities of faith as texts.

\section{NOTES:}

1 A shortened version of this article was read as a paper on 4 August 1998 at the XVIth Congress of the I.O.S.O.T. in Oslo, Norway.

2 Cf, amongst others, the following: J D Smart, The strange silence of the Bible in the church. A study in hermeneutics, Philadelphia 1970; P A Bird, The Bible as the church's book, Philadelphia 1982; C E Braaten \& R W Jenson (eds), Reclaiming the Bible for the church, Grand Rapids, Michigan 1995; P R 
Davies, Whose Bible is it anyway? JSOT Suppl. 204, Sheffield 1995; the Catholic statement "The Interpretation of the Bible in the Church" of 1993. J L Houlden (ed), The Interpretation of the Bible in the Church, London 1995 and L Ruppert \& H-J Klauck (eds), Die Interpretation der Bibel in der Kirche, Stuttgart 1995 contain discussions and evaluations of this document.

$3 \mathrm{Cf}$, e g, H Vander Goot, Interpreting the Bible in theology and the church, New York 1984.

4 Cf, e g, M A Noll, Between faith and criticism. Evangelicals, scholarship, and the Bible in America, Grand Rapids, Michigan 1991.

5 Cf the Catholic statement "The Interpretation of the Bible in the Church" (1993). R P Carroll, "Cracks in the Soul of Theology", in J L Houlden (ed), The Interpretation of the Bible in the Church, London 1995, 142-143 evaluates this document as follows: "It is deeply encouraging, on the one hand, to encounter an intelligent document emanating from the Vatican on the subject of the Bible which recognizes the integrity of the historical-critical approach to the Bible and which gives permission for the pious to use such methods by recommending many of the most contemporary approaches to reading the Bible. On the other hand, it is somewhat discouraging to discover that these encouraging features are only surface deep. This is not a critical document which embraces a fully developed critique of the Bible, incorporating the lessons of the Enlightenment into a mature and reflective reading of the Bible".

Braaten \& Jenson, op cit, $x$ also react against an overly-critical biblical criticism: "The historical-critical method was a gift to the church of the Enlightenment. ...However, the marriage between scholarly criticism of the Bible as a collection of ancient documents and the church's belief in its divinely inspired message of salvation has ever since proved to be unstable. The methods of critical reason have tended to take over the entire operation of biblical interpretation, marginalizing the faith of the church and dissolving the unity of the Bible as a whole into a multiplicity of unrelated fragments. The academy has replaced the church as the home of biblical interpretation".

6 Cf, e g, the views expressed in Semeia 73 (1996).

7 Cf particularly the various publications of $\mathrm{G} O$ West: biblical hermeneutics of liberation: Modes of reading the Bible in the South African context, Pietermaritzburg, 1991; "The relationship between different modes of reading (the Bible) and the ordinary reader", Scriptura S9 (1991), 87-110; "Some parameters of the hermeneutic debate in the South African context", Journal of Theology for Southern Africa 80 (1992), 3-13; "No integrity without contextuality: The presence of particularity in biblical hermeneutics and pedagogy", Scriptura SI 1 (1993), 131-146.

8 Cf my own contributions to this end: L C Jonker, "Bridging the gap between 'professional' exegetes and Bible readers", Old Testament Essays 10/1 (1997), 69-83; and L C Jonker, J Botha \& E M Conradie, Die Bybel in fokus. Leesgids vir 'n nuwe tyd, Cape Town 1997.

9 Cf, e g, D J A Clines, "Possibilities and priorities of biblical interpretation in an international perspective", biblical Interpretation 1/1 (1993), 67-87; Davies, op cit; and W A Kort, "Take, Read". Scripture, textuality, and cultural practice University Park, 1996. 
Cf in particular K Nielsen "A mainline Protestant view" in H S Wilson (ed), Christian fundamentalism today, Geneva 1994, 40-52; and Kort, op cit.

11 Cf inter alia the following publications: D N Fewell (ed), Reading between texts. Intertextuality and the Hebrew Bible, Louisville Kentucky 1992; T J Keegan, "biblical Criticism and the Challenge of Postmodernism", biblical Interpretation 3/1 (1995), 1-14; Kort, op cit; P D Miscall, "Texts, more texts, a textual reader and a textual writer", Semeia 69 (1995), 247-260; K Nielsen, "Intertextuality and biblical Scholarship", Scandinavian Journal of the Old Testament 2 (1990), 89-95; Nielsen, op cit, 1994; D T Olson, "biblical theology as provisional monologization: A dialogue with Childs, Brueggemann and Bakhtin", biblical Interpretation 6/2 (1998), 162-180; G Snyman, "Intertextuality, story and the pretence of permanence of canon", Old Testament Essays 8 (1995), 205-222; B D Sommer, "Exegesis, Allusion and Intertextuality in the Hebrew Bible: A response to Lyle Eslinger", Vetus Testamentum 46/4 (1996), 479-489; E van Wolde, "Trendy Intertextuality?" in S Draisma (ed), Intertextuality in biblical writings. Essays in honour of Bas van lersel, Kampen 1989, 43-49; E van Wolde, "Van tekst via tekst naar betekenis", Tijdschrift voor Theologie 30 (1990), 333-361; P M Venter, "Intertekstualiteit, kontekstualiteit en Daniël 9", In die Skriflig 31/4 (1997), 327-346; J Voelz, "Multiple signs and double texts: Elements of intertextuality" in S Draisma (ed), Intertextuality in biblical writings. Essays in honour of Bas van lersel, Kampen 1989, 27-34; J Voelz, "Multiple Signs, Levels of Meaning and Self as Text: Elements of Intertextuality", Semeia 69 (1995), 149-164; W S Vorster, "Intertextuality and Redaktionsgeschichte" in S Draisma (ed), Intertextuality in biblical writings. Essays in honour of Bas van Iersel, Kampen 1989, 15-26; M Worton, \& J Still (eds), Intertextuality. Theories and practices. Manchester 1990.

12 J Degenaar, "Textuality and Deconstruction", Paper read at a workshop on "Textuality" in the Department of Old Testament, Stellenbosch 1995.

13 Cf in this regard the film "Gabbeh", where carpet-weaving is used as a metaphor for text.

14 Cf J Derrida, "Living on: border lines" in $\mathrm{H}$ Bloom et al., Deconstruction and criticism, New York 1979, 84 who distinguishes between "text" ("a differential network, a fabric of traces referring endlessly to something other than itself, to other differential traces") and "book" ("a self-enclosed sphere of meaning").

15 Cf, e g, Carroll's discussion of Jeremiah: R P Carroll, "Intertextuality and the Book of Jeremiah: Animadversions on Text and Theory" in J C Exum, \& D J A Clines (eds), The new literary criticism and the Hebrew Bible, JSOT Suppl. 143, Sheffield 1993. The treatment of the book of Ruth by K Nielsen, "Intertextuality and Hebrew Bible", Paper read at the XVIth Congress of the I.O.S.O.T. in Oslo, Norway 1998 also falls in this narrower category.

16 Van Wolde, Tijdschrift voor Theologie 30 (1990), 336ff distinguishes between intertextuality related to textual production, and intertextuality related to textual reception.

17 Degenaar, op cit, 7.

18 Cf H Bloom, The Anxiery of Influence: A Theory of Poetry, New York 1973; and H Bloom, A Map of Misreading. New York 1975. 
20 Degenaar, op cit, 13.

$21 \quad$ Miscall, Semeia 69 (1995), 45.

22 T K Beal, "Ideology and Intertextuality: Surplus of Meaning and Controlling the Means of Production" in D N Fewell (ed), Reading between texts. Intertextuality and the Hebrew Bible, Louisville, Kentucky 1992, 27-39.

23 Cf the following statement of Nielsen, op cit, 1994, 44: "To use a metaphor we might say that a text is always part of an ongoing dialogue between older and younger texts. Our task as exegetes is therefore to try to trace this dialogue this intertextuality - through history. We are not concerned with just any intertextuality, but with the intertextuality that comes out of the historical situation in which the text was written, used and re-used, and the historical situation in which I live as a scholar and as a person".

24 Van Wolde, Tijdschrift voor Theologie 30 (1990), 341-342 criticizes views of textuality that either focus exclusively on the object (the written text), or that focus exclusively on the subject (the reader).

25 Beal, op cit, 26.

26 S Fish, Is there a text in this class? The authority of interpretive communities, Cambridge, Massachusetts 1980, 319

27 Cf Clines, biblical Interpretation 1/1 (1993), 78: "If we ask who it is that authorizes or legitimates an interpretation, who it is that says something may count as an interpretation and not be ruled out of court, the answer can only be: some group, some community, some collective that is in the business of counting and that holds court, ruling interpretations in or out. ...What we call legitimacy in interpretation is really a matter of whether an interpretation can win approval by some community or other".

28 Fish, op cit, 321.

29 Voelz, op cit, 1989 and Voelz, Semeia 69 (1995).

30 Beal, op cit, 28.

31 This view more or less corresponds to the views of Voelz, op cit, 1989, 30-31: "Often signs (events/ideas) are matrixed, i e, connected with other signs or sets of signs for interpretation with other events or ideas in some sort of a context".

32 Voelz, op cit, 1989, 32 argues as follows: "It seems also true to conclude that several types of sign sets or texts are particularly important in/for the interpretive task. That is to say, when a given matrix of signs is interpreted, certain types of (component) signs/sign sets/texts provide 'anchors', as it were, for the interpretation of all other signs within that given matrix... all signs are 'not created equal', ... some seem to be more important and more dominating than others - they are interpretive 'keys', as it were - and it directs our attention to which signs/sign sets of a given matrix serve as judge, so that their meaning is determinative for the meaning of the complex of signs under consideration as a whole" (his italics). Cf also Voelz's, Semeia 69 (1995), 160-161 section on "Validity of Interpretation and the Community" in his article on intertextuality.

33 Kort, op cit, 121.

34 Miscall, Semeia 69 (1995), $45-46$ refers to Bloom's theory about texts: “...a theory that speaks not of easy borrowings and smooth influences, but of the anxiety of influence, of the burdensome feeling of belatedness (of coming too 
late on the scene) and of the conflict with a precursor. ...For Bloom, writing and reading, which are two sides of the same coin, are dominated not by establishing meaning and truth but by confrontation with another. In the confrontation power and possession are sought; ..."

35 Degenaar, op cit, 9.

36 Cf T K Beal, op cit, 32: "If ideology is a strategy of containment, then the interpretive rules in biblical studies, which establish closure ...on the general text and legitimize certain intertextual relationships, are certainly ideological. They are, so to speak, modes of production for making sense from a surplus of intertextual possibilities".

37 Voelz, Semeia 69 (1995), 149, in a summary of what his article is about, states: "The essay ... will contend that a 'confessional' understanding of the interpretive task is not only desirable but inevitable and necessary, and that not only in a Christian context".

38 Cf K Nielsen, op cit, 1998 who concludes her paper with a section on "Responsible Exegesis Today".

39 Cf Clines, biblical Interpretation 1/1 (1993), 77: "I have to admit, of course, that, even though the church does not 'own' the Bible, biblical research would probably not exist - certainly not in the form or to the degree that it does at present - if it were not for the church. And I allow that there is, whether we like it or not ....a symbiotic relationship between the academic study of the Bible and the religious communities who esteem the Bible. But it is an uneasy relationship. The academics want to resist the church's agenda, and the church wants to resist the academy's conclusions".

40 Davies, op cit, 13.

41 Cf also the following quotations from Davies, op cit, 14: "Just as there is a need to articulate the role and meaning of the scriptures in the context of Judaism and Christianity, so there is no realistic hope of imposing an ecclesial interpretation outside the ecclesial domain. ... The discourse of the church about its scriptures, then belongs within the church domain, and cannot be extended beyond it ....while the right to a 'confessional' discourse about the scriptures must be upheld, it cannot claim a jurisdiction over how bibles are to be defined and read outside its own bounds".

42 Cf G Green, "The Hermeneutic Imperative: Reading the Bible as scripture", Nederlands Theologisch Tijdschrift 50 (1996), 29: "When one endeavours to view reality through the lenses of scripture, ...not only the biblical text but all events become deutungsbedürftig - in need of interpretation. ...If the meaning of the text is always open-ended, it follows that there can be no escape from interpretation". 